\title{
Russian-NATO Relations after the Crisis in South Ossetia in 2008
}

\author{
Elena Kropatcheva*
}

\begin{abstract}
This article analyses Russian-NATO relations and demonstrates that the South Ossetian crisis in 2008 has reflected and deepened the problems between the two actors, which have grown since 1991. Russia has felt increasingly excluded from, in Russian eyes, decisions affecting its security. Correspondingly, Russia is discontented with the current international structure dominated by NATO and aims at a renewal of the partnership on a more equal footing. Even though the tension and mistrust between them has been increasing, and only limited cooperation and 'partnership' is feasible, common interests and interdependencies will still help to avoid a new Cold War.
\end{abstract}

Keywords: Russia, NATO, South Ossetia, Georgia

Russland, NATO, Südossetien, Georgien

\section{Introduction}

$\mathrm{T}$ The day of 8 August 2008 - the start of the Olympic Games in Beijing - was supposed to symbolize peace. But the Georgian armed forces launched a military attack on Tskhinvali, the capital of South Ossetia, on the night from 7 to 8 of August with the aim to "restore the constitutional order"1 after escalation of military confrontations between Georgia and its break-away republic. As a response, Russian forces implemented a "peacekeeping operation to force Georgia to peace," i.e. military action against the Georgian army on Georgian territory, beyond the borders of South Ossetia. These events concern not only Russian-Georgian relations, but also Russian-NATO relations, taking into account that Georgia has been aspiring to membership in NATO, that the Alliance in general has been supporting Georgia's NATO-oriented foreign policy, but also that Russia's operation was interpreted by many NATO states as a proof that Russia is a threat to the smaller neighbouring countries. Thus, instead of symbolizing peace, 8 August has underlined that NATO and Russian interests increasingly clash, and that even peace between them may turn out to be fragile.

Almost 20 years after the end of the Cold war, the Russian Federation (RF) and NATO started to speak about "freezing" their relations. NATO states decided that they "cannot continue with business as usual." 2 NATO General Secretary Jaap de Hoop Scheffer announced: "the NATO-Russia Council meetings would be placed on hold until Russia adhered to the ceasefire and the future of our relations will depend on the concrete actions Russia will take to abide by the ... peace plan. ${ }^{33}$ Moreover, some NATO member

\footnotetext{
* Elena Kropatcheva is doctoral student at the Institute für Peace Research and Security Policy at the University of Hamburg (IFSH).

1 President Mikhail Saakashvili, cited in: Klussman U. The Story of Tskhinvali's Resistance, Spiegel Online, 26 August 2008.

2 Meeting of the North Atlantic Council at the Level of Foreign Ministers held at NATO Headquarters, Brussels, 19 August 2008.

3 NATO‘s Foreign Ministers Reiterate Their Support for Georgia, 8 August. Russian President Dmitri Medvedev and French President Nicolas Sarkozy negotiated a six-point peace plan to bring the conflict regarding the South Ossetia to an end. It was announced on 12 August, agreed to by Georgian President Mikhail Saakashvili also agreed on 15 August and finally signed by Russia on 16 August. The text of the peace plan can be found at: General Affairs and External Relations Council, Brussels, Doc.12453/08, 13 August 2008, pp. 6-7.
}

states suggest rethinking the Alliance's military strategy towards Russia.

Russia's NATO ambassador, Dmitri Rogozin, said that the RF decided to "freeze" co-operation with NATO on peacekeeping issues, including logistics, even though Russia would continue to work with NATO on Afghanistan. ${ }^{4}$ Furthermore, President Dmitri Medvedev underlined that "cooperation between Russia and NATO is above all in the interests of the NATO member countries, and if they break off cooperation this will not have any real impact on Russia." ${ }^{5}$ Russia's recognition of independence of South Ossetia and Abkhazia on 26 August has only added oil to the fire, and it was strongly criticized by NATO ${ }^{6}$

This article analyses Russian-NATO relations and demonstrates that the situation in South Ossetia was a litmus test to the problems, which have accumulated in Russian-NATO relations. This study first presents an overview of Russian-NATO relations since the 1990s. It explains the role of the problematic Russian-NATO relationship for Russia's reaction to the crisis in South Ossetia. Finally, the article presents the main outcomes of the South Ossetian crisis and prospects for relations between Russia and NATO.

\section{Overview of Russian-NATO Relations since 1991: Increasing Points of Contention}

After the dissolution of the USSR in 1991, the RF hoped to become "a full member of the international community," in particular, by building a common pan-European security structure with the West, where Russia would be an equal par-

4 Rossiia na polgoda zamorazhivaet mirotvorcheskoe sotrudnichestvo s NATO, zayavil Rogozin [Russia Is Freezing Peacekeeping Cooperation with NATO for a Half a Year - Rogozin], at: http://www.newsru.com/russia/26aug2008/no_ nato.html.

5 Russia Is Ready for Any Decision on Future Cooperation with NATO, $25 \mathrm{Au}-$ gust, 2008, at: http://www.kremlin.ru.

6 Cf.: Statement by the Secretary General of NATO on the Russian Recognition of Abkhazia and South Ossetia, 26 August 2008.

7 Andrey Kozyrev, cited in: Rubinstein A.Z. 1997. The Transformation of Russian Foreign Policy. In The International Dimension of Post-Communist Transitions in Russia and the New States of Eurasia, edited by Karen Dawisha,. New York: M.E. Sharpe Inc., p. 34 
Table 1. Evolution of Cooperation between NATO and the RF ${ }^{9}$

\begin{tabular}{|c|c|}
\hline 1991 & $\begin{array}{l}\text { The North Atlantic Cooperation Council (NACC) is created as a forum for consultation to foster coopera- } \\
\text { tion with the countries of Central and Eastern Europe. }\end{array}$ \\
\hline 10 March 1992 & Russia becomes a formal member of the NACC. \\
\hline 1994 & Russia joins the Partnership for Peace (PfP) programme. \\
\hline 31 May 1995 & NATO offers Russia “enhanced partnership." \\
\hline 1996 & $\begin{array}{l}\text { Russian peacekeepers serve alongside Allied counterparts in the NATO-led peacekeeping force in Bosnia } \\
\text { and Herzegovina. }\end{array}$ \\
\hline 20 March 1996 & Memorandum of understanding on civil emergency cooperation is signed. \\
\hline 27 May 1997 & $\begin{array}{l}\text { The Founding Act on Mutual Relations, Cooperation and Security between NATO and the RF is signed. } \\
\text { Permanent Joint Council (PJC) is set up as a forum for regular consultations on security issues. }\end{array}$ \\
\hline March 1998 & A permanent mission of Russia to NATO (including military representation) is established. \\
\hline 28 May 1998 & Memorandum of understanding on scientific and technological cooperation is signed. \\
\hline 1999 & Russian peacekeepers deploy as part of the NATO-led peacekeeping force in Kosovo. \\
\hline September 2001 & $\begin{array}{l}\text { Russia opens its airspace to the international coalition's campaign in Afghanistan and shares relevant } \\
\text { intelligence. }\end{array}$ \\
\hline February 2001 & The NATO Information Office is opened in Moscow. \\
\hline May 2002 & The NATO Military Liaison Office is opened in Moscow. \\
\hline 28 May 2002 & $\begin{array}{l}\text { "NATO-Russia Relations: A New Quality Declaration" is signed by Heads of State and Government of NATO } \\
\text { Member States and the RF; the NATO-Russia Council (NRC) is established to replace the PJC. }\end{array}$ \\
\hline 2003 & NATO and Russia sign an agreement on submarine-crew rescue. \\
\hline 9 December 2004 & NATO-Russia Action Plan on Terrorism is adopted. \\
\hline 2004 & Agreements establish Russian military liaison offices to NATO’s strategic command headquarters. \\
\hline 2005 & Russia signs the PfP Status of Forces Agreement. \\
\hline 2005 & $\begin{array}{l}\text { NRC defence ministers endorse a "Political-Military Guidance" aimed at developing, over time, interope- } \\
\text { rability between Russian and Allied forces. }\end{array}$ \\
\hline April 2006 & $\begin{array}{l}\text { At the NRC meeting in Sofia foreign ministers agree on a set of priorities and recommendations to guide } \\
\text { the NRC's future work. }\end{array}$ \\
\hline 2006 & $\begin{array}{l}\text { The first Russian frigate deploys to support Operation Active Endeavour (OAE), NATO's maritime counter- } \\
\text { terrorist operation in the Mediterranean. }\end{array}$ \\
\hline June 2007 & $\begin{array}{l}\text { Russia and NATO commemorate the fifth anniversary of the NRC and the tenth anniversary of the Foun- } \\
\text { ding Act. }\end{array}$ \\
\hline 2007 & A second Russian frigate deploys in active support of OAE. \\
\hline 2008 & $\begin{array}{l}\text { NATO and Russia sign an agreement allowing the land-transit across Russian territory of non-military } \\
\text { equipment destined for the NATO-led International Security Assistance Force (ISAF) in Afghanistan. }\end{array}$ \\
\hline
\end{tabular}

ticipant. However, it realised that the West was not ready to dismantle NATO and to replace it with some other new security structure. ${ }^{8}$ As a result, the RF has had to develop relations with NATO, and since the 1990s many important steps have been taken (see table 1).

Nevertheless, despite this increased density in Russian-NATO relations since the 1990s, Russia is dissatisfied with their progress. The prime reason is that the RF leadership aspired to exclusive partnership with NATO, but this 'exclusiveness' was never achieved. Russian-NATO cooperation is often described as more declaratory than real. ${ }^{10}$ The North Atlantic Cooperation Council (NACC), Permanent Joint Council (PJC), and even the NATO-Russia Council (NRC) turned out to be not as effec-

8 For more details see: Danilov D. 2005. Russia and European Security. In What Russia Sees, edited by Dov Lynch, 79-99. Paris: The EU Institute for Security Studies.

9 The table is based on the information available at: http://www.nato.int/issues/nato-russia/evolution.html, http://www.nato.int/issues/nato-russia/index.html.

10 E.g. Danilov (2005), p. 81 tive as they could have been, because difficult issues were often excluded from their agendas.

One of these issues is the question of which goals do Russia and NATO have in common and how do they intend to implement these. Will Russia ever join NATO as member? The question of Russia's membership has not been seriously discussed. Even though the Russian leadership has not ruled out such a possibility - "if and when Russia's views are taken into account as those of an equal partner," 11 - NATO's answer was that Russian membership was "not on the agenda." 12 Because NATO has not even left an option for discussing the prospect of Russia's membership, its official representatives started to underline that "Russia is not standing in line to join NATO." ${ }^{13}$ In this context, Dmitri Trenin is right in criticising the West, which "saw Russia as a special case" - "[a]rmed with nuclear weapons, its great-power mentality shaken but unbroken, and just too big":

11 Vladimir Putin's Interview in BBC Breakfast with Frost, 5 March 2000.

12 NATO Secretary General on Acting President Putin's Interview with the BBC. Press Release (2000)023.

13 Putin, cited in: Felgenhauer P. 2001. Putin Serious about NATO. Moscow Times, 29 November. 
Russia would never join NATO, but it was supposed to pursue "a generally pro-Western foreign policy." 14

At the same time, it is not only the West's fault that RussianNATO relations have not deepened to the level of close partnership or integration. Even though official Russian representatives resent Russia's 'exclusion' from the European security architecture, Russia's membership in NATO would mean that it would have to adapt to NATO military standards, because of its weaker military capabilities. Even though this would not be an obstacle to NATO membership per se, it contradicts Russia's idea about the equality of the relationship. Additionally, Russia's domestic and foreign policies have often contradicted the democratic values, which have acquired increasing importance for NATO. According to Victor Kremeniuk, in the 1990s there were discussions in NATO on a new Russian-NATO integrative security framework. The US representatives even spoke of establishing a tandem between NATO and Russia as an alternative to NATO enlargement. However, these talks ended after the start of Russia's first war in Chechnya in $1994 .{ }^{15}$

In addition to general problems in Russian-NATO relations, Russia's attitude towards NATO hardened because of several concrete steps of the Alliance and/or its members, which are presented chronologically in the following paragraphs. On 12 March 1999, the Czech Republic, Hungary and Poland became new members of NATO. Even though official Russian representatives reiterated before the enlargement that any expansion of NATO "would lead to a revival of the Russian military and a more assertive Russian policy in Eastern Europe," 16 Russia reluctantly accepted this fact. Even more bitter was Russia's reaction to the start of military operations of the enlarged NATO to end political and ethnic repression in the Yugoslav province of Kosovo on 23 March 1999. The then-President Yeltsin characterised this operation as "nothing other than naked aggression" and as "an attempt by NATO to enter the 21st century in the uniform of a world policeman." 17 This crisis impacted the new Russian security concept (2000), which warned that "a number of states are stepping up efforts to weaken Russia" and criticised the "[a]ttempts to ignore Russia's interests when solving major issues of international relations." 18 The perception hardened that instead of being integrated into the international community, Russia was excluded from it.

Another concrete issue of concern for Russia has been the US/ NATO plans since 2003 to establish military bases in Romania and Bulgaria. ${ }^{19}$ The Military Doctrine of the RF designates the demonstration of power through the build-up of military forces near Russia's borders and the deployment of foreign troops on the territories of adjacent states without Russia's agreement as a vital security threat. ${ }^{20}$ This also explains why Russia strongly criticised the new wave of NATO enlargement in 2004, when

14 Trenin D. 2006. Russia Leaves the West. Foreign Affairs, Vol. 85 (4), p. 89.

15 Author's interview with Victor Kremeniuk, Deputy Director of the US-Canada Institute, the Russian Academy of Science (RAS).

16 Evgeniy Primakov, cited in: Goble P., Russia’s Foreign Minister Primakov Sets New Tone. RFE/RL Features Article, Prague 1996.

17 Cf. Russian President Boris Yeltsin Denounces NATO's Air Strikes in Yugoslavia. 1999. PBS Online News Hour, 24 March 1999.

18 National Security Concept of the Russian Federation. 2000, at: http://www. russiaeurope.mid.ru/russiastrat2000.html

19 For more details see: Lachowski Z. 2007. Foreign Military Bases in Eurasia. SIPRI Policy Paper 18, Oxford: Oxford University Press, pp. 24-29.

20 Cf. Voennaia Doktrina Rossiiskoi Federatsii [Military Doctrine of the RF]. 2000, at: http://www.mid.ru.
Romania, Bulgaria, but also the Baltic States inter alia joined the Allies. Despite its concerns and dissatisfaction with this situation, Russia again accepted this event pragmatically, demonstrating that it could adapt even to the changes, which it viewed as unfavourable in the system of international relations. ${ }^{21}$ However, Russia's grievances towards NATO and the US aggravated, when in mid-2004 the US started talks with the Czech Republic, Hungary and Poland about the possibility of basing US missiles defense interceptors and radar in these countries.

Additionally, in 2003 and 2004, Russian-NATO relations experienced low points. These were due to their opposing positions on the Rose Revolution in Georgia and Orange Revolution in Ukraine respectively, which ignited as a result of fraud elections in these two countries and brought to power Western-oriented politicians, who have strongly been aspiring to NATO membership.

In February 2007, at the 43rd Munich Conference on Security Policy, Putin clearly stated that Russia is dissatisfied with the current status quo, when "[o]ne state and, of course, first and foremost the United States, has overstepped its national borders in every way," and this is why a new "architecture of global security" had to be designed. ${ }^{22}$ The Conventional Armed Forces in Europe (CFE) treaty has been another point of discord between Russia and NATO. As the CFE treaty was concluded between two military blocs: the NATO and the Warsaw Pact, it does not correspond to the post-Cold War reality. ${ }^{23}$ In 1999 , at the OSCE Summit in Istanbul, OSCE member-states agreed on the adaptation of the CFE treaty. ${ }^{24}$ At the same time, Russia committed to "complete withdrawal of the Russian forces from the territory of Moldova by the end of 2002" 25 and to disband two of its bases in Georgia by 1 July $2001 .{ }^{26}$ As this has not happened, NATO states saw no "basis" to "work towards bringing the adapted Treaty into force." ${ }^{27}$ Russian official representatives object to this linkage. In December 2007, Russia suspended its participation in the adapted (CFE) treaty, because "[s]even years have passed and only four states have ratified this document," including the RF. ${ }^{28}$.

2008 was especially replete with challenges for Russian-NATO relations. Even though Russia opposed Kosovo's declaration of independence in February, many NATO states (e.g., the US, UK, France, Germany) proceeded with recognition. Thus, the situation was repeated similar to the one in 1999: Russia's concerns and opposition did not keep most NATO states from acting. In April 2008, NATO members agreed at the Summit in Bucharest that Ukraine and Georgia "will become members of NATO,"

21 Interview with Vladimir Baranovsky, Deputy Director of the Institute of World Economy and International Relations at the RAS (IWEIR/RAS) in 2005, Moscow.

22 Putin's Speech at the $43^{\text {rd }}$ Security Conference in Munich in 2007, at: http:// www.securityconference.de.

23 For more information see: Pal Dunay, Either Bring the Adapted CFE Treaty into Force or Do Not - But Face the Consequences, OSCE Yearbook 2003, pp. 259-290.

24 Istanbul Document. Agreement on Adaptation of the Treaty on Conventional Armed Forces in Europe, November 1999, pp. 119-235.

25 Istanbul Document. Istanbul Summit Declaration, p. 50.

26 Cf. Joint Statement of the RF and Georgia, Istanbul, 17 November 1999, point 1, Annex 14 of the Final Act of the Conference of the States Parties to the Treaty on CFE, CFE.DOC/2/99.

27 Cf. NATO, Final Communiqué, Ministerial Meeting of the North Atlantic Council, 24 May, 2000, Florence.

28 Ibid. 
and that Membership Action Plans (MAP) would be the "next step" for them, ${ }^{29}$ even though the decision on MAP was postponed to the next NATO Summit in December the same year. Russia has been very critical about the possibility of a further round of NATO enlargement. Moreover, the US plans for an anti-missile defense system near Russian borders became more concrete with agreements between the US and the Czech Republic and Poland respectively. Finally, in August 2008, Russia's and NATO's positions divided over the situation in South Ossetia.

This short overview demonstrates that problems in RussianNATO relations have been accumulating and intensifying. The general direction of this relationship remains unclear, mutual mistrust is growing, and their competition for influence in different regions (e.g. Georgia, Ukraine, the former Yugoslavia) has been increasing. Russia disagrees with the status quo of the international security system, where NATO and the US play the leading role, while its own concerns are dismissed. Russia is no longer ready to tolerate this situation.

\section{Russia's Rsponse to the South Ossetian Crisis as a Reflection of Problems between Russia and NATO}

Traces of the problems in Russian-NATO relations presented in the section above can be found in Russia's response to the South Ossetian crisis. In many interviews, the official representatives of the RF overtly or covertly blamed the US and other NATO states for having supported Georgia, because they "had rather encouraged the irresponsible and unpredictable regime [of Saakashvili] as it proceeded along the road of gambles." 30 The Russian MFA commented: “...over recent years while pumping Georgia up with arms Washington kept assuring us that those steps were not directed against Russia," but Georgia's actions have demonstrated "[t]he real worth of such assurances," as many Russian citizens in South Ossetia were injured or killed. ${ }^{31}$

Through its reaction to Georgia's actions, when, according to the Russian foreign minister, "Saakashvili and those who stand behind him [primarily NATO countries] ... had decided on testing Russian power for strength," 32 Russia had demonstrated that it was ready to oppose the West, in order to protect its interests. Furthermore, Victor Kremeniuk noticed that some Russian politicians have interpreted NATO's decision to postpone the decision about MAP for Ukraine and Georgia until December as a 'deadline' until which Russia could try to prevent the two states from getting the go-ahead for membership prospect, and that afterwards it would be too late to change anything. ${ }^{33}$ One possible explanation why Russia did nothing to prevent Georgia's attack on Tskhinvalli is that the Russian leaders could

29 Bucharest Summit Declaration Issued by the Heads of State and Government Participating in the Meeting of the North Atlantic Council in Bucharest on 3 April 2008.

30 Transcript of Speech by Russian Minister of Foreign Affairs Sergey Lavrov at the Foreign Ministry's MGIMO University on the Occasion of the New Academic Year, 1 September, 2008, Document 1275-01-09-2008.

31 Russian MFA Information and Press Department Commentary in Connection with Agreement to Deploy Elements of US Strategic Missile Defense System in Poland, Document 1220-20-08-2008.

32 Cf. footnote 31.

33 Author's interview with Kremeniuk. have hoped that the West would learn from Saakashvili's actions that Georgia was not mature enough to be a member of NATO. However, while NATO states were criticising Russia for its "disproportional" response ${ }^{34}$ and discussing the possibility of sanctions, they continued to praise Georgian democracy even after the attack on Tshinvalli. ${ }^{35}$ When on 20 August a US-Polish agreement on missile defense base was signed, official Russian representatives interpreted it as an anti-Russian move, because " $[\mathrm{t}]$ he timing of the signing of the American-Polish agreement, affecting the security of many European states, was not accidental." ${ }^{36}$ As a response to this perceived provocation, Russia recognized the independence of South Ossetia and Abkhazia six days later. If the West had taken a more balanced approach towards this crisis, Russia possibly would not have gone so far as to recognize their independence.

NATO was shocked to see Russia bring its forces into Georgia and to target and occupy Georgian territory. NATO member states had gotton used to Russian warnings of 'adequate' measures to safeguard its interests, not followed by action. However, they have ignored that Putin's Russia has changed. In Russian domestic political debates the idea prevails that Russia is no longer on its 'knees,' because it is much stronger economically than in the 1990s: Russia's economy has experienced uninterrupted economic growth, high energy prices gave Russia high revenues, and it paid many of its international debts. The EU depends on Russia's energy, and Russia and the Western states are interdependent in many ways. Putin has consolidated the country internally. Even though economic problems remain and Putin's political course - the strong state vis-à-vis a weak society, which has so far been continued by Russia's new president Dmitri Medvedev, is likely to contribute to the country's weaknesses in the long run, in a widely-spread perception, Russia can still afford to take unilateral decisions.

In sum, during the crisis in South Ossetia, Russia reacted not only to the actions of Georgia but also to its plans to become a member of NATO and to NATO's support of these plans, in spite of Russia's objections, but also to the status quo of the international security system, in which Russia's interests and concerns have not been taken seriously.

\section{Outcomes and Prospects for Relations be- tween Russia and NATO}

The crisis in South Ossetia has once again underlined and, at the same time, increased the problems, which exist in Russian-NATO relations. Without solutions to key issues in Russian-NATO relations and of the European security architecture in general, more crises can be expected. Because key issues are not solved, mutual mistrust lingers in all areas of relations; tension has been increasing, and provocative actions have become more frequent. As a way out from this conceptual pat situation, on 5 June 2008, Dmitri Medvedev made a proposal on "drafting and signing a legally binding treaty on European security in which the organisations currently working in the Euro-Atlantic

\footnotetext{
34 Cf. footnote 3.
}

35 Cf. President Bush's Statement on 15 August 2008, White House Press Release, Washington, DC.

36 Russian MFA Information and Press Department Commentary in Connection with Agreement to Deploy Elements of US Strategic Missile Defense System in Poland, Document 1220-20-08-2008. 
area could become parties." ${ }^{37}$ Nadezhda Arbatova notes that it is necessary to return to the point of defining the 'rules of the game' in international security - which was not done in the 1990s, because this will define whether Kosovo, South Ossetia and Abkhazia remain exceptions from the international law or whether these cases will be followed by others. ${ }^{38}$ In other words, it is necessary to return to the point, from which Russian-NATO relations went wrong. According to Victor Kremeniuk, "Helsinki-2" - as the proposed document is often named - is needed, because the aim of "Helsinki-1" 39 was to define rules of jointly accepted behavior for Russia and the West during the Cold war, but it did not go beyond that. This is why "Helsinki-2" is needed to regulate Russian-Western relations in the post-Cold War conditions. ${ }^{40}$

Even though Russian official representatives call for a new system of international security, including a new role for Russia, they have so far failed to make concrete suggestions. According to Konstantin Eggert, Russia has itself contributed to the failure of the old world order - of the old system of international law, but the consequences of that are not even clear to Russia itself. ${ }^{41}$ Russian policy-makers have to elaborate Russia's long-term goals and concrete strategies, if they want to be taken more serious by their Western colleagues. Moreover, Russia still has to become the democracy it aspires to be, because its own policies have undermined NATO's trust towards it. Instead of consolidating the country, by using the image of the West as an enemy, Russian policy-makers need to concentrate on strengthening the economy and rule of law. Instead of interfering into the affairs of its neighbouring states, Russia has to concentrate on solving the problems in its own conflict regions, such as the North Caucasus. Dmitri Medvedev started his presidency by calling for a modernisation, ${ }^{42}$ and only a modernised Russia can be attractive for other countries. Russia needs the West to succeed in this modernisation.

NATO states for their part have to learn to take Russia's concerns and apprehensions more serious, especially that Russian leadership has difficulties with long-term planning, and much is done emotionally on the basis of 'learning by doing.' NATO has to decide whether it wants to engage Russia as a partner, even if this implies discussions on difficult principal issues, or whether it wants to further contribute to Russia diversifying its foreign policy. According to Kremeniuk, the West has been pushing Russia closer to the so called 'rogue states,' as Russia and these (e.g. Cuba, Iran, Venezuela) have something in common: they are dissatisfied with the status quo in international relations. NATO should take the role of a more mature and rational (rather than emotional and provocative) partner in relations with a teenager-like Russia. NATO should engage into a dialogue with Russia on 'new rules of the game' in the international security system, making concrete proposals on how to engage Russia, reaffirming the rule of international law and peaceful means

37 Dmitri Medvedev. Speech at Meeting with German Political, Parliamentary and Civic Leaders, 5 June 2008, at: http://www.kremlin.ru.

38 Author's interview with Nadezhda Arbatova, Head of the Center of European Integration, Institute of World Economy and International Relations, RAS, Moscow, October 2008.

39 Cf. The CSCE Final Act, Helsinki 1975.

40 Interview with Kremeniuk.

41 Author's interview with Mr. Eggert, editor-in-chief of the BBC in Russia, Moscow, 2008.

42 Medvedev's Speech at Inauguration Ceremony as President of Russia, 7 May 2008, at: http://www.kremlin.ru. of conflict resolution, reviving the disarmament agenda and strengthening arms control mechanisms. NATO has to think of how to engage Russia in the antimissile defence system on an equal basis, if it is not directed against Russia, or to accept that Russia will be trying to take countermeasures. NATO has to postpone the steps, which Russia would perceive as further provocations (e.g. NATO enlargement, dislocation of military bases near Russia's territory) until relations reach a new level of trust. NATO states have to stop utilizing the enemy perceptions of Russia in their domestic political campaigns. Finally, NATO has to rethink its policy towards post-Soviet countries, which lack stability and which tend to interpret NATO's support as unconditional. Instead of supporting the anti-Russian sentiments in post-Soviet countries, NATO has to use its influence to teach these states to seek constructive formulas of relations with their important neighbour.

In spite of all problems in Russian-NATO relations and despite 'freezing' rhetoric, Russia and NATO are far from a new Cold war. While 'freezing' some areas of their relations after the South Ossetian crisis, Russia and NATO continue to cooperate in others, in particular on Afghanistan. The financial crisis in 2008 also underlined that the Western states and Russia have to work together in order to prevent the financial system from failing. Russian-NATO relations had many low points and crises, but nevertheless, as the table above demonstrates, their cooperation has been ongoing. Russia and NATO need to join forces on different soft and hard security issues (border management, piracy, maritime search and rescue, organized crime, trafficking, ensuring WMD non-proliferation, anti-terrorism, etc.). Additionally, as Kremeniuk noted, NATO and Russia share concerns regarding the expansion of Islamic radicalism, of climate warning, and regarding relations with such states as China, Iran, and others, who may endanger the whole European security. ${ }^{43}$ Russia remains interested in cooperation with NATO. Even though Russia acted unilaterally in the case of South Ossetia (and Abkhazia), ignoring the protests of NATO states, the RF leadership aims at maintaining constructive cooperation with the West. This was the gist of numerous interviews of official Russian representatives with different Western mass media.

Russia and NATO will continue to cooperate in some areas, while in others their relations will remain highly problematic. A true partnership and cooperation in all areas is currently impossible, because of mutual mistrust. Moreover, the questions of a new wave of NATO enlargement and of US/NATO military bases and of US anti-missile system near Russia's borders may become more acute. Russia has been a difficult and often unpredictable 'partner' for NATO, and Russia and NATO have been increasingly drifting apart on a number of issues. Nevertheless, NATO's (even if unintentionally) provocative policies have been aggravating the difficult legacy Russia and NATO inherited from the Cold War period, which they still have to overcome. Common interests and interdependencies in important security issues will, however, prevent the escalation of confrontation into a new Cold War. Russia and NATO have to work on building trust in order to prevent the Georgian scenario in other regions (e.g. Ukraine).

43 Ibid. 